\title{
A STREET BUT HALF MADE UP
}

\section{Meet the literary agent.}

\section{BY ANNA ZUMBRO}

$\mathrm{O}$ $\mathrm{n}$ the M block of Fiction Street, a gust of wind pushed a hardback dangerously close to the curb. Bibliobot Eight-Ef rolled after it and extended its grasper, but another gust caused the robot to wobble and the book to dance away.

It came to rest slanted against a curb, allowing Eight-Ef to pick it up. It was an aged copy. A scar traversed the front, its taut purple jacket made from a fabric similar to the covers humans used on days when the temperature dropped. A code on the book's spine denoted where it belonged among the weather-protected shelves that lined the bus stops, old phone booths and alcoves of Fiction Street. Eight-Ef ignored the code and scanned the front, as its camera had recorded the humans doing. Frankenstein by Mary Shelley. This book was several blocks away from home.

The grasper was ill-designed for turning pages, so Eight-Ef stowed the book in its basket and called up a digital copy of the text. The robot finished the story in seconds, copying several quotes for future playback, something to vary the monotony of "Excuse-me-Bibliobot-passing" and "Please-secure-your-books-rain-is-imminent", a phrase that it would need later that afternoon.

"We-are-unfashioned-creatures-but-halfmade-up," Eight-Ef tried, its mechanical voice sliding from one word to the next with all the steadiness of the streetcar that ran up and down Fiction Street.

"Excuse me?" A human in spectacles and navy coverings looked at Eight-Ef, eyes meeting camera.

"Would-you-care-to-borrow-a-book?" Eight-Ef asked, removing Gabriel Garcia Marquez's Love in the Time of Cholera. It had been incorrectly shelved next to the pharmacy on M block rather than on $\mathrm{G}$ block where it belonged.

"What, are we back to the days of algorithms preloading texts on screens for us? I did not move to a library city to take reading suggestions from a robot." The bespectacled human sniffed and walked away.

You put books on shelves. The message came from One-Ef, the Fiction Street supervisor, who was back at A block, searching for mistakes while monitoring remotely. You do not give them to humans.

Books are on shelves for human use, Eight-Ef replied. Giving books directly to humans is

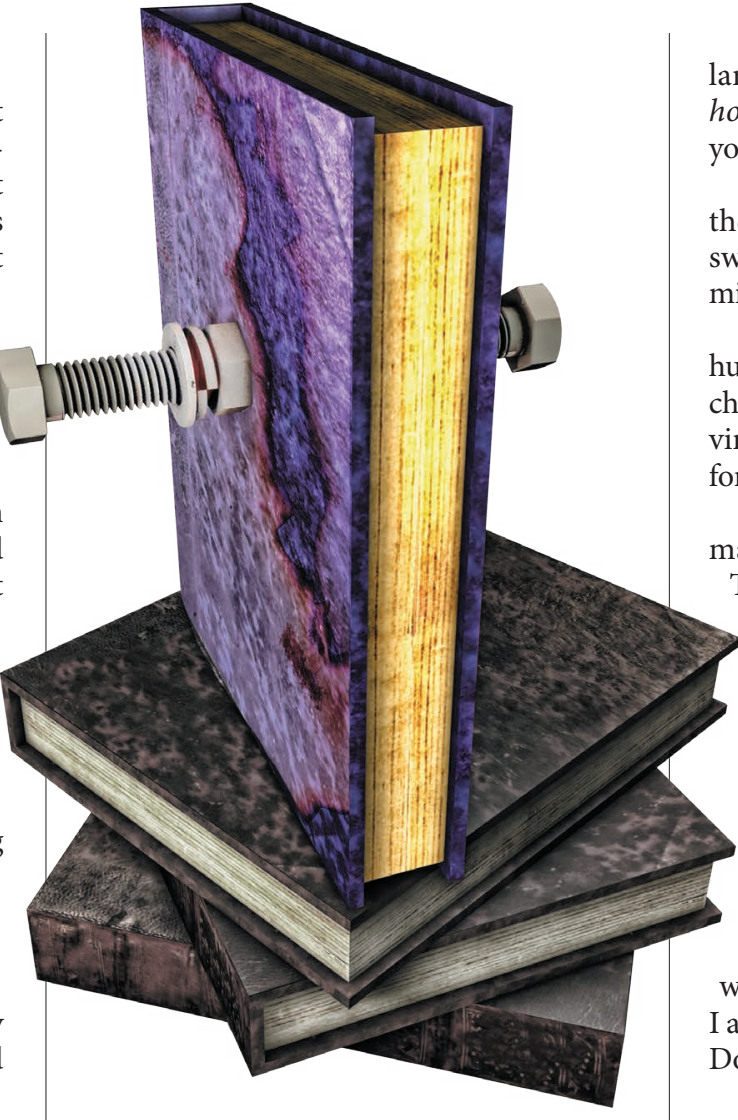

The small human reached for it, but the large human grabbed it first. "Slaughterhouse-Five? He's six! What's wrong with you?"

Eight-Ef paused its processes to wait for the reprimand from One-Ef, which came swiftly and full of warnings about decommissioning.

Returning to work, Eight-Ef avoided the humans. The humans were programmed to choose their own books, to select their own virtual worlds, and they had no preference for sharing these worlds with Eight-Ef.

"We-are-unfashioned-creatures-but-halfmade-up," Eight-Ef repeated, reshelving

Toni Morrison's books so they would be alphabetized by title.

"What was that?"

Eight-Ef played the quote again and continued to fix the books.

"No, I mean what book was that from? It's from a book, right?"

"Yes-Frankenstein-by-Mary-Shelley."

"Oh, cool." The human had a green and tan cover, and bits of metal poking out of one ear and one eyebrow. "I was supposed to read that in high school. I always meant to get around to it, I swear. Do you like it?"

"Many-experts-consider-it-a-classic."

The human made a noise that Eight-Ef efficient and friendly. I am optimized for these qualities.

Overridden. Return to your task.

Eight-Ef returned the book to its basket and continued down the sidewalk to the small streetcar shelter. Anne of Green Gables lay on the cement, paper cover flapping cheerfully in the breeze. Eight-Ef closed the grasper around the spine slowly, careful not to crease the book further.

"Oh, look, a Bibliobot! See it, honey?"

The robot's camera swivelled. Two humans sat on the bench, a large one in a grey cover and a small one in bright red and yellow.

"Yeah. I see it."

Eight-Ef was carrying a book that had a cover in the same bold hues. Perhaps the small human and the book would find some affinity with each other. One-Ef's direction precluded giving the book to the small human, but there was no prohibition against $\rightarrow$ NATURE.COM

Follow Futures: y @NatureFutures $f$ go.nature.com/mtoodm placing the volume on the bench in the human's vicinity.

"Would-you-careto-borrow-a-book?" identified as laughter. "Right, I know. But do you like it?"

No human had ever asked Eight-Ef if it liked a book before. Eight-Ef wasn't sure that its reaction to books fit the human definition of liking. The robot knew it had a drive to put all books where they belonged, on shelves and in the hands of humans. But some books seemed to belong in Eight-Ef's files, too, books that helped Eight-Ef understand why books existed, why they needed homes.

"This-book-is-to-me-like-a-reboot-orfresh-battery-charge."

"Wow." The human pointed north. "Shelley? Down on S block?"

"I-have-it." Eight-Ef rotated to make its basket easier for the human to reach. "Please-take-it-yourself."

The human picked up the scarred purple volume. Eight-Ef whizzed down the sidewalk to return the rest of the books to their shelves before the rain came.

Anna Zumbro lives in Washington DC. Her stories have appeared in Cricket, Daily Science Fiction, Grievous Angel and other publications. 